\title{
REDUCING PREDATION THROUGH CHEMICALLY MEDIATED CAMOUFLAGE: INDIRECT EFFECTS OF PLANT DEFENSES ON HERBIVORES
}

\author{
John J. Stachowicz ${ }^{1}$ AND Mark E. HAY ${ }^{2}$ \\ University of North Carolina at Chapel Hill, Institute of Marine Sciences, 3431 Arendell Street, \\ Morehead City, North Carolina 28557 USA
}

\begin{abstract}
Herbivores often specialize on particular hosts that provide both food and shelter from natural enemies. It is thus often unclear whether a plant's value as a food or its value as a safe shelter has played a larger role in selecting for specialization. Decorator crabs offer a novel opportunity to investigate the relative effects of diet vs. natural enemies in selecting for specialization because these crabs place plant "shelter" on their backs as camouflage but need not use these plants as food, thus decoupling the plant's value as a food from its value as a shelter. In this study, we show that juveniles of the decorator crab Libinia dubia selectively decorate with the chemically defended brown alga Dictyota menstrualis but treat this plant as a low-preference food. Common omnivorous fishes that are potential predators of Libinia avoid consuming Dictyota due to the alga's potent chemical defenses. In the field, juvenile crabs decorated with Dictyota experience significantly less predation than crabs decorated with an alga that is not chemically noxious to local fishes, and the Dictyota metabolite that most strongly deters feeding by fishes is the specific metabolite that determines decoration choice by this crab. Thus, by behaviorally sequestering defenses from this chemically noxious plant, these small crabs reduce their susceptibility to predation. In the presence of predators, juvenile crabs reduce their rate of feeding, but not of decorating, suggesting that antipredator behavior such as decorating takes precedence over feeding. In addition, only juvenile crabs that are of a size that can be consumed by local fishes decorate at all. Adult crabs that have carapace widths exceeding the gape size of co-occurring fishes do not decorate in either the field or the laboratory. Apparently predation, rather than diet selection, drives decoration specialization in Libinia, highlighting how indirect effects of plant secondary chemistry can impact herbivore behavior, ecology,
\end{abstract} and evolution.

Key words: associational defense; chemical camouflage; decorator crab; Dictyota; enemy-free space; herbivory; Libinia; marine chemical ecology; North Carolina, USA; plant-herbivore-predator interactions; seaweed; specialization.

\section{INTRODUCTION}

Although it is well established that many herbivorous insects feed on only a small fraction of the species potentially available to them, the factors selecting for this specialization have been the subject of considerable debate. Several authors have suggested that the need for "enemy-free space" (Price et al. 1980, 1986, Bernays and Graham 1988, Bernays 1989) may be more important in selecting for host-plant specialization than chemical coevolution between plants and herbivores (Ehrlich and Raven 1964). While this assertion may be controversial (Barbosa 1988, Courtney 1988, Ehrlich and Murphy 1988, Fox 1988, Jermy 1988, Rausher

Manuscript received 11 November 1997; revised 16 March 1998; accepted 20 March 1998.

${ }^{1}$ Present address: Department of Marine Sciences, University of Connecticut, 1084 Shennecossett Road, Groton, Connecticut 06340 USA.

E-mail: jstach@uconnvm.uconn.edu

${ }^{2}$ Present address: School of Biology, Georgia Institute of Technology, Atlanta, Georgia 30332-0230 USA.
1988, Thompson 1988), it serves to point out that a major, yet underexplored, influence of plant chemistry on herbivory may be through mediation of interactions between herbivores and other selective factors such as predation or disease (Hay et al. 1987, Schultz 1988, Hay 1992, 1996, Hunter and Schultz 1993).

Plant secondary chemistry is a demonstrably important factor affecting food selection by a wide variety of both terrestrial (Bernays and Chapman 1987, Rosenthal and Berenbaum 1992) and marine (Hay and Steinberg 1992, Paul 1992) herbivores. However, our knowledge of the ultimate reasons why herbivores are attracted to, or deterred by, plant chemicals is poor; this is in part because direct and indirect effects of secondary metabolites on consumer fitness can be confounded and complex and can vary as a function of the herbivore species being tested (Bryant et al. 1992, Hay and Steinberg 1992, Rowell-Rahier and Pasteels 1992, Slansky 1992). In numerous instances, plant secondary metabolites affect herbivores both directly, through food quality, and indirectly, through mediation of in- 
teractions with pathogens and predators or through use as an indicator of favorable microclimates for development (Rausher 1988, Bernays 1989, Dicke et al. 1990, Schultz et al. 1990, Kibota and Courtney 1991, Hay 1992, 1996, Rowell-Rahier and Pasteels 1992). The relative importance of these direct and indirect pathways may yield important clues to the selective forces driving the evolution of herbivores, for they indicate whether the primary selective force at work is related to food quality, natural enemies, or recognition of appropriate microhabitats.

Experimental evidence from both marine and terrestrial systems has shown that plant secondary chemicals often mediate herbivore specialization and that some specialist herbivores reduce the effectiveness of their natural enemies by using these plant metabolites to enhance their own fitness. For example, gypsy moth caterpillars feed primarily on oaks. Although the tannins in oak leaves reduce gypsy moth fecundity, the tannins also inhibit a virus that is lethal to gypsy moths and can limit their population size; consuming these tannin-rich plants can, therefore, produce a net benefit for gypsy moths (Schultz et al. 1990, Hunter and Schultz 1993). Specialization is generally less common in marine than terrestrial systems (Lubchenco and Gaines 1981, Hay and Fenical 1988, Hay 1992), and its relative rarity can provide an advantage in studies trying to assess factors selecting for specialization (Hay et al. 1990, Hay and Steinberg 1992). There are several examples of small marine herbivores that specialize on one or only a few related species of chemically defended seaweeds (see review in Hay 1992). In one example, the amphipod Ampithoe longimana preferentially consumes brown algae in the genus Dictyota, which are avoided by omnivorous fishes (Hay et al. 1987, Duffy and Hay 1991). Because they are chemically defended from fish grazing, Dictyota plants in the field are visited less frequently by fishes, and amphipods living on these plants experience less predation than those living on seaweeds that are more palatable to fishes (Duffy and Hay 1994). By living and feeding on chemically noxious plants, these amphipods, and other small sedentary herbivores, reduce their susceptibility to predators (reviewed in Hay and Fenical 1996). However, because these herbivores use the same plant for both food and protection from enemies, the direct and indirect effects of secondary chemicals in selecting for host preference cannot be easily separated.

To discriminate between the direct effects of chemistry on diet selection and the indirect effects on susceptibility to natural enemies requires an herbivore for which selection of food and shelter are not confounded. Several crabs in the family Majidae, called decorator crabs, appear to be good test subjects in this regard. These crabs cover their carapace with seaweeds or benthic invertebrates from the surrounding environment, presumably in an attempt to camouflage themselves from predators (Wicksten 1980, 1983). Because many of these decorator crabs are herbivorous, they offer a novel opportunity for discriminating between the factors governing food and habitat selection in small herbivores because the camouflaging material that they place on their backs affords them a portable habitat but does not have to be used for food. Thus, the selection of a plant as habitat (camouflage material) does not directly limit the dietary options available to these herbivores.

The decorating behavior of these crabs has typically been described (primarily anecdotally) as visual camouflage from predation (Wicksten 1980, 1983). The crabs reduce movement and attempt to match the background, which is thought to reduce the likelihood of detection by predators. However, there have been no investigations into whether this behavior actually reduces predation in the field, and few experimental determinations have been made of the proximate or ultimate factors used in selection of decorating material (but see Kilar and Lou 1986). Camouflage behavior mediated by deterrent plant secondary metabolites might be even more effective than simple visual camouflage because (1) the crab would appear to be an item recognized as unpalatable and thus one that should be avoided; and (2) if discovered and taken into a predator's mouth, the deterrent compounds present in the camouflage might cause the predator to reject the crab as a suitable prey (as occurs in some amphipods that build domiciles of chemically noxious algae [see Hay et al. 1990]). Rigorous examples of chemically mediated camouflage behavior are relatively rare in both terrestrial and marine systems (see review by Stowe 1988), but studies of this phenomenon could provide insight into the relative importance of direct and indirect effects of secondary metabolites on herbivore behavior, and potentially on ecological and evolutionary factors favoring specialization (Futuyma and Moreno 1988, Thompson 1994).

In this investigation, we assess diet and camouflage selection by the decorator crab Libinia dubia and the role that plant secondary chemistry may play in these processes. Specifically, we address the following questions: (1) What materials does L. dubia use as camouflage in the field, and how does this compare to the availability of these materials in the environment? (2) How does breadth of diet compare with breadth of camouflage selection and do these choices vary with the size (and presumably age) of the crab? (3) Is selection of camouflage material mediated by deterrent plant chemicals? (4) Does the preferred camouflage material reduce the crab's susceptibility to predators relative to a less preferred camouflage material? and (5) Do the crabs modify their feeding and camouflaging behavior in response to predation risk?

\section{Methods}

Organisms and study site

Field surveys and experiments were conducted in seagrass beds (0.1-0.5 m deep at low tide) at Mitchell 
Village, in Morehead City, North Carolina, USA. Seaweeds such as the red algae Hypnea musciformis and Gracilaria tikvahiae, and the brown alga Dictyota menstrualis, also occurred here attached to small rocks, shells, seagrass, or polychaete worm tubes. Dictyota menstrualis produces several diterpene alcohols, some of which serve as potent feeding deterrents against fishes (dictyol E), sea urchins (pachydictyol A and dictyol E), and some amphipods (dictyol E) (Hay et al. 1987, 1988, Duffy and Hay 1994, Cronin and Hay 1996a, $b$ ). This brown alga is common in a variety of shallow water habitats from southern Virginia to the Caribbean (Schneider and Searles 1991). Organisms for laboratory experiments were collected at Mitchell Village and several similar grass bed sites near the University of North Carolina's Institute of Marine Science in Morehead City, North Carolina.

The decapod crab Libinia dubia occurs throughout its range from Cape Cod, Massachusetts, to the Texas Gulf Coast and the northern Caribbean. Juveniles are found clinging to seagrass blades in shallow water and are often covered with various sessile invertebrates or seaweeds, while the carapaces of adults are typically clean (Williams 1984). We could find no published studies that addressed either the feeding habits of this crab or whether the "overgrowth" that occurred on its carapace settled and grew there or was actively placed there by the crab, but preliminary experiments demonstrated that the crabs rapidly replaced this material when it was removed from the carapace. Because we wanted to focus on how the crabs used seaweeds as both food and camouflage, most of our assays used only juvenile crabs (size range 6-21 $\mathrm{mm}$ carapace width), although we did do one assay with larger, adult individuals (38-53 $\mathrm{mm}$ carapace width) for comparative purposes. Unless otherwise noted, any mention of $\mathrm{Li}$ binia refers to juveniles. Although Libinia is a predictable member of the seagrass community, juveniles occur at low densities and are generally uncommon, constraining the sample sizes of our assays with this organism $(N=11-22$ juvenile Libinia $)$.

\section{Field surveys}

To assess which materials Libinia selects for camouflage in the field, we collected 18 crabs from the Mitchell Village grass beds and quantified the composition of their camouflage. Crabs were too small and cryptic to collect by sight, so we pushed a long-handled dip net $(43 \times 30 \mathrm{~cm}$ opening with $0.3 \mathrm{~cm}$ diameter mesh cloth) along the bottom of the grass bed for several meters, then removed any crabs found in the net. In order to obtain 18 crabs we had to sample an area roughly $10 \times 100 \mathrm{~m}$, and we never caught more than one crab per trial, so it is likely that the crabs we collected were representative of those found at this site. The camouflage material was removed from the back of each crab, blotted dry with a paper towel, and weighed to the nearest $1 \mathrm{mg}$. If the total mass of a particular type of camouflage (e.g., algal species) on a given crab was $<1 \mathrm{mg}$, we arbitrarily assigned it a mass of $0.1 \mathrm{mg}$. The wet mass of each species used as camouflage by each crab was converted to a percentage of the total wet mass of camouflage on that crab for comparison with percent-cover data on the availability of camouflage material in the field.

In order to determine if crabs were selectively using some materials for decoration, we estimated the availability of decoration materials by assessing the percent cover of sessile organisms at the site where the crabs were collected, using a point-intercept method. At 19 randomly selected locations along a $100-\mathrm{m}$ transect, we placed a $0.5 \times 0.5 \mathrm{~m}$ frame with 100 random points marked by the intersection of pieces of string. We compared the mean percent cover of each sessile organism with its relative abundance as camouflage (percentage of total wet mass). Although comparing mass with percent cover could be a problem if potential camouflage items differed in their growth form (i.e., encrusting vs. arborescent), all the species we encountered in this survey have upright, arborescent growth forms, so the relationship between mass and percent cover should be similar for all species. Because data often were bimodal or exhibited highly skewed distributions that violated the assumptions of parametric tests, we used nonparametric Mann-Whitney $U$ tests to compare use as decoration vs. availability in the field.

\section{Whole-plant food and camouflage choice}

In the laboratory, we assessed the dietary and camouflage preferences of Libinia by offering crabs a simultaneous choice of eight common species of seaweeds. All these seaweeds occur in shallow waters of North Carolina in the early summer: the green alga Ulva rigida, the brown algae Padina gymnospora, Dictyota menstrualis, and Dictyota ciliolata, and the red algae Hypnea musciformis, Agardhiella subulata, Chondria dasyphylla, and Gracilaria tikvahiae. Because stress can affect algal palatability to herbivores (Renaud et al. 1990, Cronin and Hay 1996a), we minimized algal stress by placing the seaweeds in coolers with fresh sea water for transport to the laboratory, sorting and holding the algae in flow-through seawater tanks upon arrival (within $0.5 \mathrm{~h}$ of collection), and beginning all assays within $6 \mathrm{~h}$ of collection. We stripped each crab of existing camouflage, and placed it in a separate 0.5 -L bowl $(N=19$ crabs $)$ with four 1 $\mathrm{cm}$ diameter holes to allow for flow-through seawater. Each bowl with a crab held a 125-150 mg piece of each of the eight seaweed species (i.e., a choice assay). As a control for changes in seaweed mass unrelated to herbivory or camouflaging, 19 identical bowls without crabs contained same-sized pieces of the same species of seaweed. Within each replicate, treatment and control pieces of algae were taken from the same algal thallus. After $33 \mathrm{~h}$, each piece of alga was blotted dry with a paper towel and reweighed; camouflage was then 
stripped from crabs and weighed. As a comparison, we also assessed the feeding and decorating preferences of adult Libinia ( $N=9$ individuals) using the same procedure with larger containers $(1.4 \mathrm{~L})$ and larger masses of each seaweed (450-550 mg).

To calculate net mass loss for each algal species due to crab feeding in the choice assays, we corrected for mass changes unrelated to herbivory using the formula $\left(T_{i} \times\left[C_{f} / C_{i}\right]\right)-\left(T_{f}+D\right)$, where $T_{i}$ and $T_{f}$ are the initial and final masses of the seaweed portion in the container with a crab, $C_{i}$ and $C_{f}$ are the initial and final masses of the seaweed portion in the paired control container, and $D$ is the amount of the seaweed used as camouflage. Results are reported as mass of algae consumed per 33 h. Crabs never consumed, or used as camouflage, $100 \%$ of any of the choices, so preference for an alga as camouflage did not make that alga unavailable for consumption, and vice versa. Because the amount of each species consumed or used as camouflage may depend on what other choices are available (i.e., the factors are not independent [cf. Peterson and Renaud 1989]), we analyzed choice data using the nonparametric Friedman's two-way test on ranked data, which allows for dependence among treatments, provided that each replicate is independent (Conover 1980). Comparisons among species were made using Friedman's multiple comparisons test. In simulations this test has performed well, with low Type II error rates for analyzing multiple choice assays with a large number of choices and replicates (Aldredge and Ratti 1986).

As a contrast for our crab feeding and camouflage preferences, we also measured feeding preferences of a temperate omnivorous fish (the pinfish, Lagodon rhomboides) by simultaneously offering six species of seaweed to 12 individual fish isolated in separate flowthrough aquaria. Two of the algal species (Dictyota ciliolata and Agardhiella) used in the crab feeding assay were not available in sufficient quantity at the time when we conducted the fish feeding assay and were not used. A 40-L aquarium was divided in half by a piece of cloth netting (0.5-cm mesh openings), and a pinfish was placed in one of the two halves. We placed 190-220 mg pieces of each seaweed species between the strands of $0.25 \mathrm{~m}$ long pieces of braided polypropylene rope weighted with galvanized nails, and placed a rope in the half of each aquarium holding a pinfish. As a control for changes in algal mass unrelated to herbivory, we placed equivalent ropes, with pieces of the same species of algae, in the half of each aquarium that did not have a pinfish. As with the crab assay, within a replicate, treatment and control pieces of algae were cut from the same thalli, and all algae were removed and reweighed after $33 \mathrm{~h}$. Changes in mass due to herbivory were calculated and differences between species analyzed using the same methods outlined for the crab assay.

\section{Relative predation risk for adult vs. juvenile Libinia}

In both field surveys and laboratory choice assays, juvenile crabs strongly preferred the chemically defended alga Dictyota menstrualis for camouflage, while adults did not camouflage at all. Within a species, larger individuals are commonly less susceptible to predators than smaller ones (e.g., Vince et al. 1976, Hughes and Elner 1979), so we reasoned that the absence of decoration by adults might reflect a reduced benefit of camouflage due to the decrease in predation risk associated with increasing size. To provide support for this idea, we determined the potential of grassbed fishes to consume juvenile and adult Libinia by comparing the size of the fishes' mouths with the size of these crabs. We chose this measure because, for predatory fishes, the upper size of prey consumed is often set by gape (e.g., Werner 1974, 1977, Wainwright and Richard 1995, Wainwright 1996). Mouth gape was measured to the nearest $0.1 \mathrm{~mm}$ using a dial caliper for three common species of grass bed fishes: adult pinfish (95-155 $\mathrm{mm}$ total length [TL]), juvenile gag grouper, Mycteroperca microlepis (137-155 mm TL), and oyster toadfish, Opsanus tau (112-176 mm TL). We chose these species because they are common predators of crabs in grass beds on the east coast of the United States (Schwartz and Dutcher 1963, Adams 1976a, Wilson et al. 1982, Motta et al. 1995, Ross and Moser 1995), and include a range of fish-mouth types found in these habitats. Fishes were collected by crab pot, minnow trap, and seine from grassbeds near the study sites and represent the range of sizes typically encountered during mid to late summer (Schwartz and Dutcher 1963, Adams 1976b, Ross and Moser 1995). Although there are no data available on the historical abundance of larger predators in North Carolina seagrass beds prior to human exploitation, pinfish, toadfish, and juvenile groupers are not targets for human exploitation in these habitats, so recent fishing pressure is unlikely to have altered the size distributions of these fish from historical levels.

\section{Chemical mediation of camouflage selection}

To determine if secondary chemistry plays a role in mediating juvenile crabs' decorating preferences, we assessed whether chemical extracts and pure metabolites from $D$. menstrualis stimulated camouflage behavior when applied to other, less-preferred, algae. The bioassays for testing the activity of crude extracts, fractions, and pure metabolites all followed the same methodology. The extract, fraction, or pure compound of interest from $200 \mathrm{mg}$ of plant was dissolved in $100 \mu \mathrm{L}$ of diethyl ether and coated onto the surface of a 200$\mathrm{mg}$ piece of the green alga Ulva using a $100-\mu \mathrm{L}$ wiretrol pipette (Drummond Scientific, Broomall, Pennsylvania). The ether evaporated within a few seconds, leaving only the lipophilic compounds on the surface of the alga. Previous studies have found that $93 \%$ of 
pachydictyol A (one of the diterpene alcohols present in D. menstrualis) coated onto palatable algae remained on the surface of the alga after being immersed in seawater for $24 \mathrm{~h}$ (Hay and Fenical 1988). Unfortunately, we could not use a piece of Ulva coated with only ether (no extract) as our control, because crabs tear algae into small pieces before using them as camouflage, and we would not have been able to distinguish whether the pieces of algae used as camouflage were from extract-treated or control plants. Instead, as a control we used a 200-mg piece of Hypnea coated with $100 \mu \mathrm{L}$ of ether. This alga served as an appropriate control because crabs exhibited no preference between Hypnea and Ulva in our eight-species choice assay and because crabs offered a paired choice between ether-coated Ulva and ether-coated Hypnea also treated the two species equally.

For this assay, we cleaned crabs of any existing camouflage, placed them in bowls like those used in the whole-alga choice assay, and offered them a choice between a piece of extract-treated and a piece of control alga. We always began assays in the late afternoon and ended them within $24 \mathrm{~h}$. At the end of the assay, the amounts of Hypnea and Ulva on the backs of each crab were collected and weighed to the nearest $1 \mathrm{mg}$. The amounts of extract-treated and control algae used in camouflage were compared statistically using a paired $t$ test, or a Wilcoxon signed-rank test where distributions were distinctly bimodal or did not meet other assumptions of parametric tests.

\section{Extraction and bioassay guided separation of extracts}

The extraction and separation methods were adapted from Cronin et al. (1995) and follow their recommendations for maximizing extraction efficiency and minimizing compound degradation. Dictyota menstrualis was collected from the Mitchell Village grass bed and returned to the laboratory within $20 \mathrm{~min}$, where we placed 200-mg (blotted wet mass) pieces of the alga in individual glass vials. We extracted each piece three times with $5 \mathrm{~mL}$ of 2:1 dichloromethane (DCM) : methanol $(\mathrm{MeOH})$, filtered the extract through a plug of glass wool, and evaporated the solvents under a slow stream of $\mathrm{N}_{2}$ gas. This crude extract was dissolved in $100 \mu \mathrm{L}$ of diethyl ether and assayed for effects on crab camouflaging preference.

The crude extract increased preference for Ulva over Hypnea, so we further partitioned the extract using chromatography with Florosil (a silica gel impregnated with $\mathrm{Mg}$ to enhance its ability to trap chlorophyll [Floridin, Berkeley Springs, West Virginia, USA]). The crude extract from 200-mg pieces of Dictyota was dissolved in $2 \mathrm{~mL}$ of hexanes and added to a small column containing $500 \mathrm{mg}$ Florosil. The vial containing the extract was rinsed with another $1 \mathrm{~mL}$ of hexanes and added to the column. After the $3 \mathrm{~mL}$ of hexanes passed through the column and we had collected the eluate in a vial, another $3 \mathrm{~mL}$ of hexanes was suctioned through the Florosil column; this comprised fraction 1 . We then passed $6 \mathrm{~mL}$ of $65: 35$ hexanes:ether through the column and collected this fraction in a separate vial (fraction 2). A third fraction was collected by passing $6 \mathrm{~mL}$ of ether through the column. The hexanes fraction should elute highly nonpolar compounds, while the hexanes/ ether mixture should contain the dictyols and sterols, and the ether fraction should contain more polar compounds including pigments (Cronin et al. 1995). We confirmed that only the ether/hexane fraction contained dictyols, by comparison with standards using thin-layer chromatography (TLC) with 1:1 ether/hexane as the eluting solvent. Fraction 2 (the dictyol fraction) was kept separate, fractions 1 and 3 were combined, and these two extracts were assayed for effects on camouflage preference.

Because only coating with fraction 2 significantly increased preference for Ulva, we concentrated further steps on the contents of this fraction. Sterols are abundant in all algae, and are thus unlikely to contribute to the observed preference for D. menstrualis as camouflage. Thus, we reasoned that pachydictyol A and/ or dictyol E (the two other compounds most abundant in fraction 2) were responsible for the observed activity. Another dictyol-class compound, dictyodial, also occurs in this fraction, but it is unstable and separation methods for this compound have yet to be developed, so we could not assay the effects of this compound alone. Because of the difficulty in quantitatively separating pure compounds from crude extracts of D. menstrualis, we opted to measure the concentrations of these compounds in fraction 2 using analytical highperformance liquid chromatography (HPLC), then use pure compounds from stock solutions to test for activity at measured natural concentrations.

To quantify the concentration of compounds in fraction 2, we used an analytical HPLC system consisting of a Waters 510 solvent pump, a $20-\mu \mathrm{L}$ sample loop, a $4.6 \times 100-\mathrm{mm}$ silica column with $3-\mu \mathrm{m}$ particle size and $10-n m$ pore size (Rainin Instrument, Emmeryville, California, USA), and a Spectra-Physics RI detector (model SP8430), all controlled by Millennium 2000 software. Peak area determinations were made using the Millennium software's integration function. We constructed calibration curves for the analyses from 35 replicate $20-\mu \mathrm{L}$ injections of $0.5-25 \mu \mathrm{g}$ of pachydictyol $\mathrm{A}$ and $1-50 \mu \mathrm{g}$ of dictyol $\mathrm{E}$. The eluting solvent was $8.5 \%$ ethyl acetate in iso-octane. Once natural concentrations for pachydictyol A and dictyol E were known, we assayed the two compounds both together and separately for effects on camouflage preference. We ran all three assays (pachydictyol A only, dictyol E only, and pachydictyol A + dictyol E) simultaneously so that results could be compared to look for additive or synergistic effects of these compounds on camouflage preference.

Both compounds together, and dictyol E alone, in- 
creased camouflaging with Ulva by the same magnitude, and pachydictyol A alone had no effect. However because dictyol E occurs at 5-6 times the concentration of pachydictyol A, we could not determine unambiguously whether crabs cued specifically on dictyol E, or simply on some threshold concentration of a dictyolclass compound. To test this, we simultaneously ran two more bioassays: one in which the treatment consisted of Ulva coated with dictyol $\mathrm{E}$ at its natural concentration, and a second in which the Ulva was coated with pachydictyol A at the higher concentrations that are typical of dictyol E.

\section{Field predation assay}

To determine if the strong preference for decorating with Dictyota menstrualis decreased predation on crabs, we compared field predation rates on crabs camouflaged with this preferred decoration species vs. a low preference camouflage species, the palatable red alga Hypnea musciformis. Thirty-six crabs were cleaned of all camouflage and divided into two groups; one group was allowed to camouflage with only $D$. menstrualis, while the other group was allowed to use only Hypnea. After $24 \mathrm{~h}$, each crab had covered its carapace with approximately the same mass of whichever alga it had been given. We tethered crabs by first blotting dry a small spot on the back of each crab's carapace without disturbing the camouflage, and then placing the free end of the monofilament line into a small droplet of Duro quick-gel no-run super glue (Loctite Corporation, Rocky Hill, Connecticut) on the dry part of the carapace. We then pipetted $\sim 1 \mathrm{~mL}$ of seawater onto the glue droplet, which accelerated the bonding process. After allowing the glue to set for $\sim 15$ $\mathrm{s}$, we attached the free end of the tether to a large metal staple that could be pushed into the substrate in a grass bed, then placed crabs in individual flow-through containers overnight, until we were ready to deploy the experiment.

To aid in placing and relocating the crabs in the field, we positioned a $36 \mathrm{~m}$-long transect line between two stakes at opposite ends of the grass bed, and marked each 2-m distance along the line. We marked each staple with either a gray or a brown cable tie to denote whether the crab tethered to it was camouflaged with Hypnea or Dictyota, then pushed the staple into the sand $0.5 \mathrm{~m}$ from the transect. The cable tie was fastened at a position on the staple that was below ground when the tethers were deployed to avoid attracting potential predators. We put crabs decorated with Dictyota or Hypnea on opposite sides of the transect, and the side on which we placed each species was alternated haphazardly. After all the crabs were placed, we removed the transect line to prevent a single predator from discovering an association between the line and the availability of crabs and consuming the entire array of crabs. After $24 \mathrm{~h}$, we replaced the line to aid in relocating all pairs of tethers, noting for each pair whether the Dic- tyota or Hypnea camouflaged crabs were still present. We analyzed for significant differences in the number of Dictyota vs. Hypnea-camouflaged crabs missing at the end of the experiment using a $G$ test.

If predation caused differences in survival of crabs decorated with Dictyota vs. Hypnea, this could have been due to either differences in quantity of the camouflage or the species composition of the camouflage. Although the amount of camouflage on crabs placed in the field did not appear to differ, we tested this more rigorously by quantifying decoration when crabs were offered only one seaweed, either Hypnea or Dictyota (a no-choice assay). In plastic bowls identical to those used in previous assays, crabs with their carapace cleaned of camouflage were offered $200 \mathrm{mg}$ of either Hypnea or Dictyota $(N=13$ crabs for each alga). After $24 \mathrm{~h}$, the material used in camouflage was removed from each crab and weighed to the nearest $1 \mathrm{mg}$. The amounts of Hypnea and Dictyota used as camouflage were compared statistically by an unpaired $t$ test.

Although differential predation could account for differences in retention of crabs decorated with Dictyota vs. Hypnea, camouflage with different seaweeds might also alter the strength of hydrodynamic forces operating on crabs. This could cause Dictyota-camouflaged crabs to be differentially susceptible to being ripped from their tether compared to Hypnea-camouflaged crabs. We could not exclude predators in the field without drastically reducing flow (e.g., with cage enclosures), so we attempted to address this possibility in the laboratory, after collecting field data on which to model our laboratory assays. As a measure of water movement at the field site while our predation experiment was deployed, we fastened chalk dissolution blocks to staples similar to those used to secure the tethers. We collected these blocks after $24 \mathrm{~h}$, then dried and re-weighed them, using the percentage change in mass as a relative measure of flow. We then adjusted a series of recirculating pumps in a flow-through water table to match net water movement in the field by recording the dissolution of chalk blocks over a 24-h period. Seven pairs of crabs were prepared as for the field experiment, one of each pair camouflaged with only Hypnea and one with only Dictyota, and each tethered to a metal staple. Each pair of crabs, with a chalk dissolution block, was placed into the water table with recirculating pumps. After $24 \mathrm{~h}$, we noted whether each tether was still intact and reweighed the chalk blocks for comparison of total flow with field data.

\section{Effects of predator presence on crab behavior}

Because much of the crab behavior we observed in the field and laboratory appeared to be driven by predator avoidance, we wanted to determine if Libinia altered its feeding or camouflage behavior as a function of changing risk of predation. Inside 30 ten-liter plastic tubs full of seawater, we placed two smaller (0.5-L) containers with perforations to allow water exchange 
Fig. 1. (A) Field surveys from the Mitchell Village grass beds of the abundance of sessile organisms expressed as percentage of total cover based on random quadrat samples; and (B) camouflage materials on the decorator crab $\mathrm{Li}$ binia dubia, expressed as the percentage of the total wet mass of camouflage on each crab. (Data show means +1 SE.) We analyzed for differences between the relative abundances of each item in the field and as camouflage using the Mann-Whitney $U$ test. Significant differences $(P<0.05)$ are indicated by the fill of the bars as indicated on the figure (black bars indicate that abundance was greater on crabs than in the field, white bars indicate that cover was greater in the field than on the crab, and shaded bars indicate no significant difference).

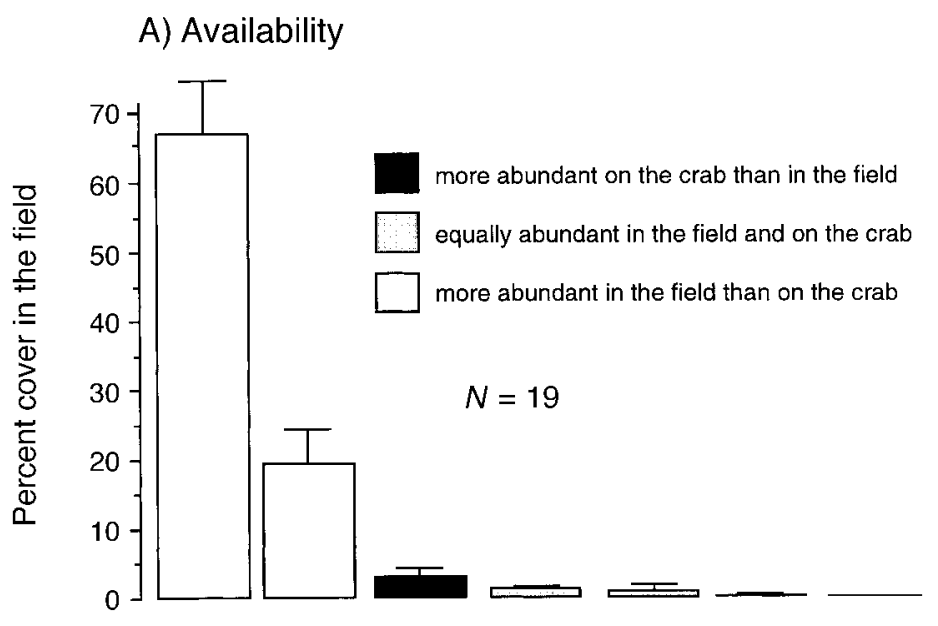

B) Use

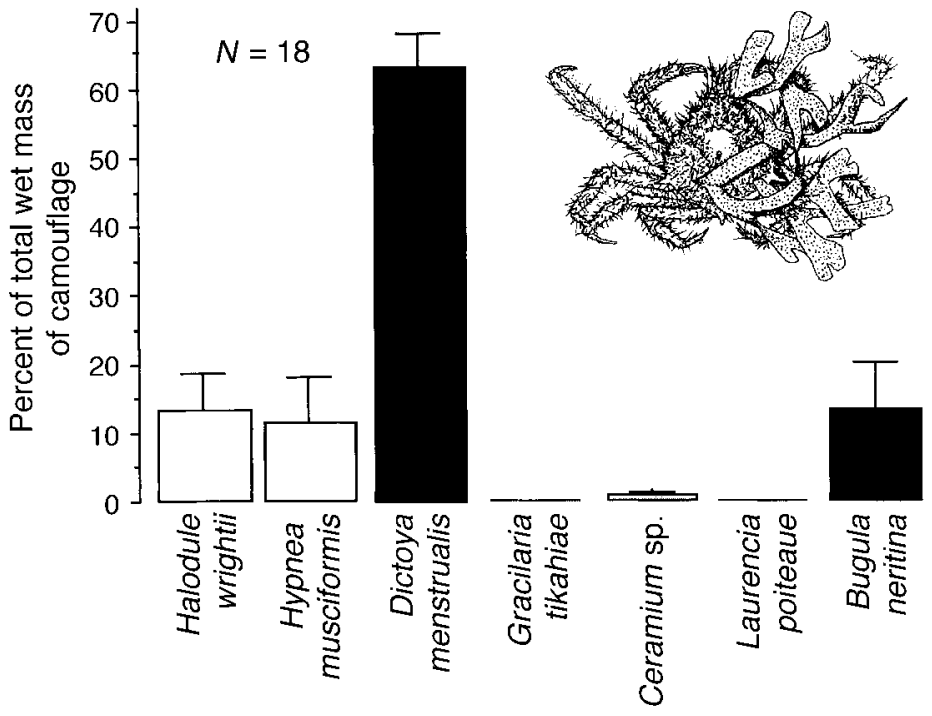

Results

with the tub. To half of the tubs, we added a single pinfish, and in one of the two smaller containers in each tub, we placed a crab that had just been stripped of its camouflage. After waiting $30 \mathrm{~min}$ to allow the crabs and pinfish to adjust to the new environment, we placed a piece of Dictyota and a piece of Hypnea (200$240 \mathrm{mg}$ blotted wet mass) in each of the 0.5-L bowls. One of the bowls thus served as a control for changes in algal mass unrelated to the activities of the crab, while the other measured consumption and camouflage use by crabs either in the presence or absence of a potential predator. After $24 \mathrm{~h}$, we reweighed each piece of alga, and removed and weighed the camouflage on the backs of crabs. The amounts of seaweed consumed and used as camouflage were calculated as in the multiple-choice assay. Data for feeding and camouflage were analyzed separately by two-way ANOVA with predator presence and seaweed species as fixed factors.
In the field, juvenile Libinia decorated selectively rather than simply matching their background. The community of sessile organisms at Mitchell Village was dominated by Hypnea (18\% cover) and the seagrass Halodule wrightii (67\% cover), with Dictyota menstrualis being rare (3\% cover) (Fig. 1A). In contrast, crabs' camouflage was dominated $(63 \%)$ by $D$. menstrualis (Fig. 1B). This species was proportionally much more abundant on crabs than in the field (Fig. 1, $P<0.0001$ ), was the most abundant material on 13 of 18 crabs, and was present on all but one of the crabs examined. The bryozoan Bugula neritina was also selectively used for camouflage $(P<0.0001)$, but much less so than Dictyota. It occurred on only 5 of the 18 crabs examined, but was very rare at our field site. We never recorded Bugula from our field percent-cover 

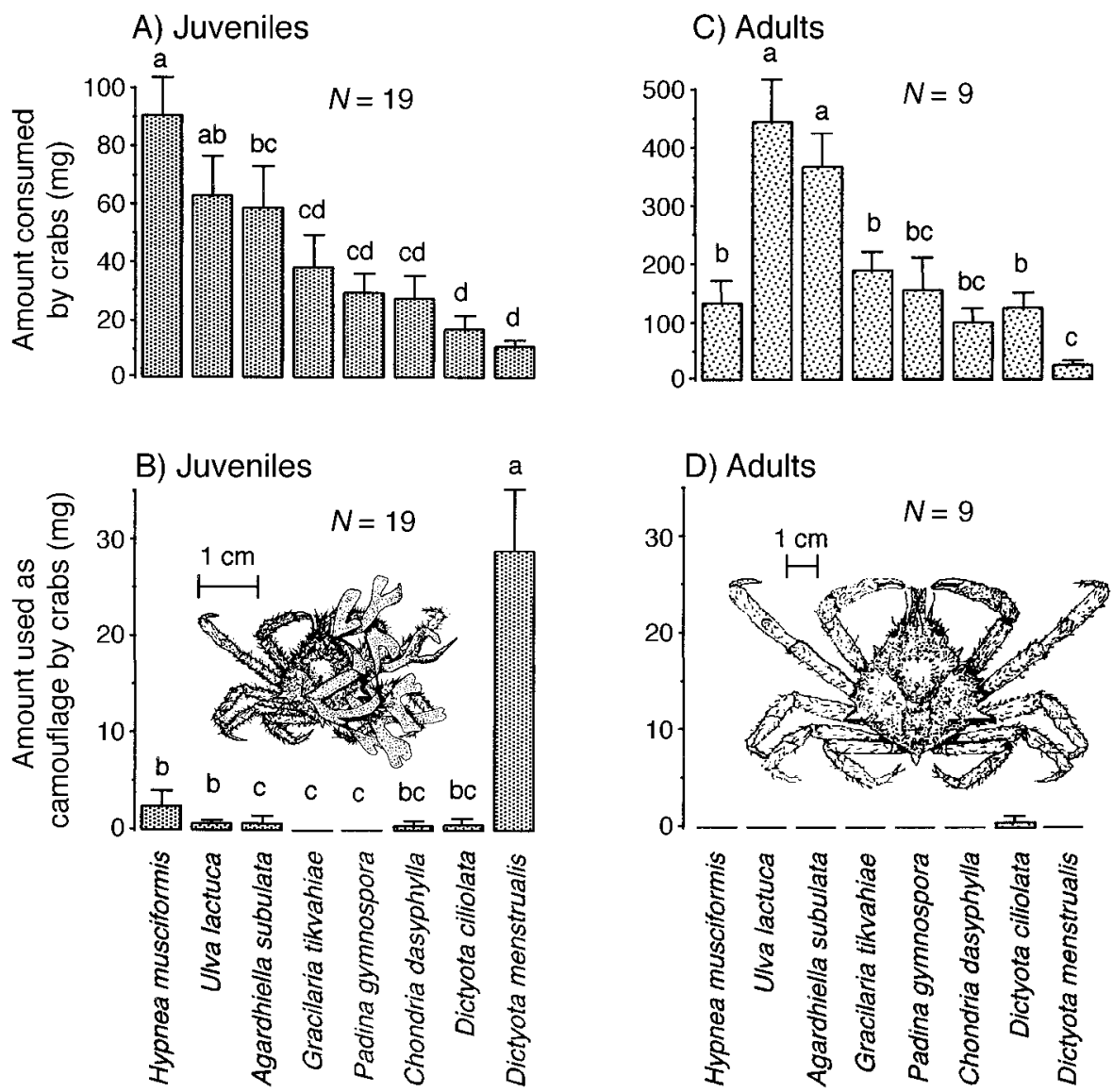

FIG. 2. Laboratory feeding and camouflage assays: selection of seaweeds for consumption and decoration by juvenile (A and B) and adult (C and D) Libinia dubia when given a simultaneous choice of eight species. $(N=$ no. paired replicates in these multiple-choice assays; data show means +1 SE.) Note different scale for drawings of adult and juvenile crabs. All assays ran for $33 \mathrm{~h}$. We analyzed the data for each experiment using the Friedman nonparametric two-way analysis of variance with multiple comparisons. The same letter above two or more bars indicates no significant difference $(P>0.05)$ between those species.

plots, however all the Bugula individuals found on the backs of crabs were very small and might have been missed by our percent-cover method. Because these bryozoans were so small, it was unclear whether the crabs had actively placed Bugula on their carapaces or whether larvae had settled and metamorphosed amongst the bristled setae on the carapace that normally hold the camouflage in place. Halodule and Hypnea were used less frequently than expected from their abundance $(P<0.0001$ and $P=0.0002$, respectively). None of the nine adult crabs collected in the field had any camouflage on their carapace.

When given equal masses of eight seaweeds, juvenile crabs were highly selective in choosing camouflage but showed less selectivity in feeding (Fig. 2A, B). These crabs camouflaged almost exclusively with Dictyota menstrualis; the amount of $D$. menstrualis used per crab was greater than for any other species $(P<0.05$, Friedman's multiple comparison test; Fig. 2B), and for all other species combined (paired $t$ test, $P=0.0176$ ). Other species were rarely used and differed from each other only slightly. As food, Hypnea was preferred over all species except for Ulva $(P<0.05$, Friedman's twoway nonparametric ANOVA, Fig. 2A). Agardhiella, Gracilaria, Padina, and Chondria were of intermediate preference and did not differ from each other, while the two Dictyota species were of low preference. Thus, juvenile crabs camouflaged almost exclusively with a seaweed that they preferred not to consume (D. menstrualis), and they preferred to consume a seaweed that they avoided using as camouflage (Hypnea) (Fig. 2A, B). Adult crabs exhibited feeding preferences similar to those of the juveniles (with the exception of reduced consumption of Hypnea); however adults rarely decorated with any of the seaweeds (Fig. 2C, D).

The mean gape sizes of grass bed fishes were considerably smaller than the diameter of adult Libinia (Fig. 3), and none of the fishes' gapes were as large as our smallest adult crab, suggesting that adults may be relatively unlikely to be preyed upon by fishes in these inshore habitats. In contrast, the mouth gapes of grass bed fishes are similar in size (pinfish) or larger than 
FIG. 3. Gape width of three species of grass bed fishes compared with the carapace width (indicated by the spanning line below the crab) of juvenile and adult Libinia dubia. Vertical lines indicate the range of observations. The number of crabs or fish measured $(N)$ is given at the base of each bar.

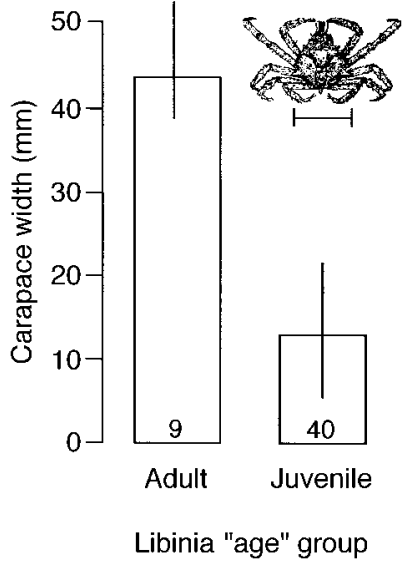

(grouper, toadfish) the carapace diameter of juvenile Libinia (Fig. 3), suggesting that these crabs might be much more susceptible to consumption by fishes in the field. Thus, only those crabs most likely to be preyed upon by fishes appear to decorate.

In a laboratory choice assay using six of the eight species offered to crabs, the pinfish (Lagodon rhomboides) exhibited feeding preferences similar to those of Libinia (Fig. 4). Pinfish consumed considerable amounts of Hypnea, Ulva, Chondria, and Gracilaria, with more Hypnea than Gracilaria being consumed (Friedman's two-way nonparametric ANOVA, $P<$ 0.05); Padina and Dictyota menstrualis were avoided almost completely. The favored camouflage of juvenile crabs was strongly avoided by the fish (Figs. 2B and 4).

Assays coating extracts of Dictyota menstrualis onto Ulva suggested that the preference of the crabs for camouflaging with $D$. menstrualis was chemically mediated. The initial assay comparing Libinia preference for Hypnea vs. Ulva in a choice assay when both algae were coated with only ether showed that there was no significant preference for either alga (Fig. 5A; $P=$ $0.560)$. When Ulva was coated with the lipophilic crude extract of $D$. menstrualis, it was significantly preferred over Hypnea that had been coated with only ether (hereafter referred to as "control") (Fig. 5A; $P=0.009$ ). When this crude extract was partitioned by Florosil chromatography, only the fraction containing the dictyols increased camouflage preference (Fig. 5B; $P=$ $0.028)$. Ulva coated with the remainder of the DCM crude extract $(100 \%$ ether fraction $+100 \%$ hexanes fraction) had no effect on crab preference in camouflaging $(P=0.730)$.

Results from analytical HPLC indicated that the natural concentration of pachydictyol A in D. menstrualis collected from Mitchell Village was $0.077 \pm 0.014 \mathrm{mg} /$ $\mathrm{g}$ wet mass while that of dictyol $\mathrm{E}$ was $0.438 \pm 0.082$ $\mathrm{mg} / \mathrm{g}$ wet mass (means $\pm 1 \mathrm{sD} ; N=7$ Dictyota individuals). A mixture of pachydictyol $\mathrm{A}$ and dictyol $\mathrm{E}$
FIG. 4. Consumption of seaweed by the pinfish Lagodon rhomboides when given a simultaneous choice of six species of seaweed. $(N=$ no. paired replicates of these multiple-choice assays). Order of species on the horizontal axis is as in Fig. 2 for ease of comparison with crab feeding and decoration preferences. Data analysis and symbols are also as in Fig. 2.

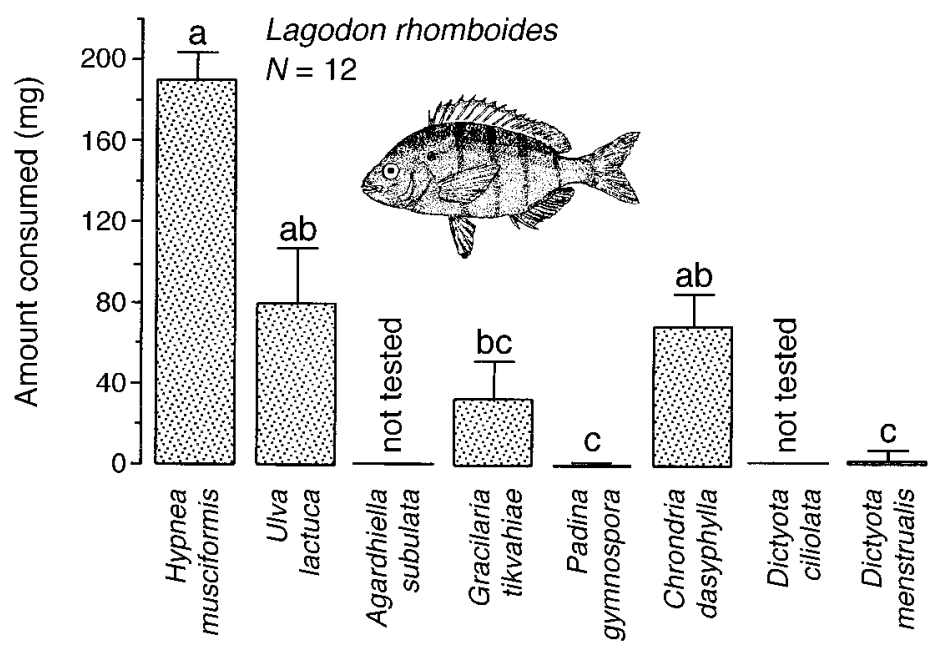




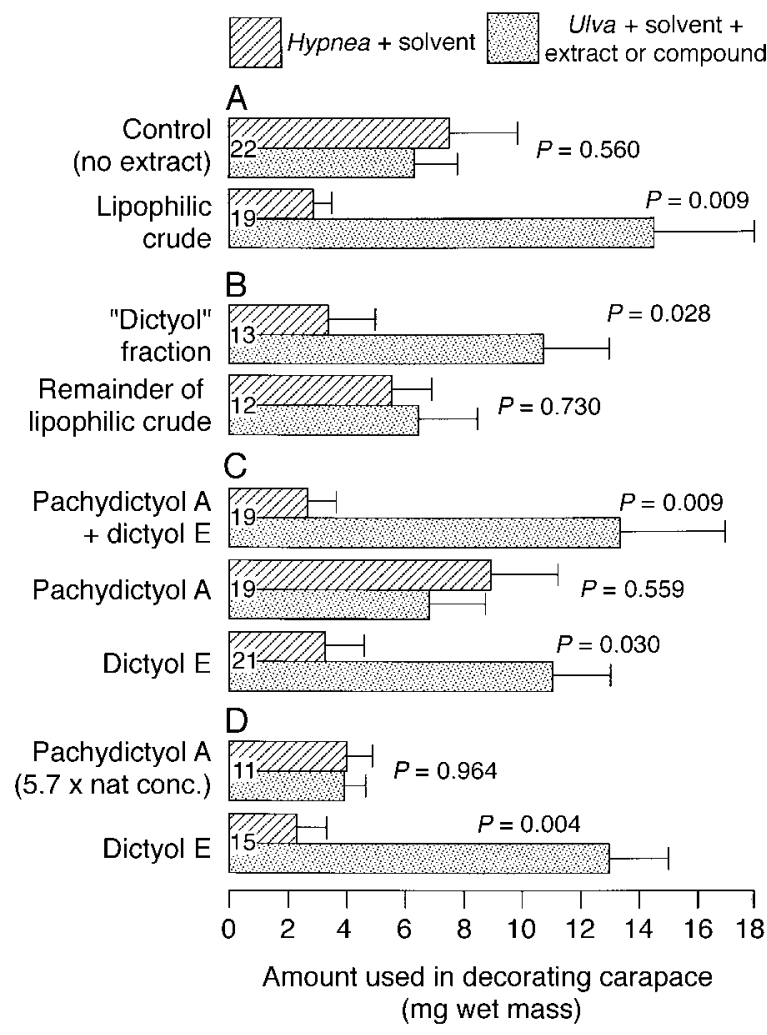

FIG. 5. The effects of Dictyota menstrualis secondary chemistry on camouflage preference of the decorator crab Libinia dubia. (A) Lipophilic crude extract and controls; (B) Florosil column partitioning of the lipophilic crude extract; (C) pure metabolites at natural concentration; and (D) pure metabolites at elevated (pachydictyol A) or natural (dictyol E) concentrations. Each pair of bars represent the mean (+ $1 \mathrm{SE}$ ) amount of treatment (Ulva + extract or compound) and control (Hypnea + solvent control) algae used in camouflage by the crab. We analyzed these data using paired $t$ tests, or Wilcoxon signed-rank tests where assumptions of parametric tests could not be met, and $P$ values for each assay are indicated on the figure. The number of crabs used in each assay $(N)$ is given at the base of each pair of bars.

at natural concentration significantly increased crab preference for camouflaging with Ulva relative to the control (Fig. 5C; $P=0.009$ ). Ulva coated with pure dictyol $\mathrm{E}$ at natural concentration also increased camouflaging relative to the control (Fig. 5C; $P=0.030$ ), while pure pachydictyol A at its natural concentration had no effect on crab camouflage selection $(P=0.559)$. There appeared to be no additive or synergistic effects of the two compounds, as the magnitude of the effect of dictyol $\mathrm{E}$ alone and pachydictyol A + dictyol $\mathrm{E}$ did not differ $(P=0.544$, unpaired $t$ test on the difference between amount of treatment and control algae used in decoration for dictyol $\mathrm{E}$ alone vs. pachydictyol $\mathrm{A}$ and dictyol $\mathrm{E}$ together). Even when the concentration of pachydictyol A was increased by 500\%, to equal the natural concentration of dictyol $\mathrm{E}$, it still did not alter crab decorating preference (Fig. 5D), suggesting that the crabs cue specifically on dictyol E, not simply a threshold concentration of any dictyol-class compound.

The species composition of camouflage significantly affected survivorship of juvenile crabs in the field. Crabs camouflaged with only D. menstrualis were consumed much less frequently than crabs camouflaged with only Hypnea (Fig. 6, $N=18$ pairs of crabs, $P=$ $0.004, G$ test). When given no choice, crabs camouflaged with equal amounts of Dictyota and Hypnea (unpaired $t$ test, $P=0.872$ ), so the difference in field survivorship was not a consequence of the amount of camouflage used, but rather its species composition. In addition, camouflaging with Hypnea vs. Dictyota did not alter the likelihood that the tether would be broken in the absence of predators in the laboratory (6 of 7 crabs remained on tethers after $24 \mathrm{~h}$ for both species). Net water movement measured by chalk dissolution blocks was indistinguishable between the laboratory control and the field experiment $(N=5$ blocks in the field and $N=7$ blocks in the laboratory, Mann-Whitney $U$ test, $P=0.372$ ).

The presence of a potential predator significantly reduced feeding but had no impact on the amount or species composition of the camouflage used. ANOVA indicated no significant effect of predator presence on the amount of camouflage used (Fig. 7A, $P=0.610$ ) and no interaction between predator and camouflage species $(P=0.842)$, indicating that crabs preferred Dictyota over Hypnea for camouflage $(P=0.0002)$ regardless of predator presence. In contrast, crab feeding was reduced by $50 \%$ in the presence of predators (Fig. 7B, $P=0.025$, two-way ANOVA). We could demonstrate no significant interaction between predator presence and the seaweed species chosen as food $(P=$ $0.081)$; crabs always preferred Hypnea over Dictyota $(P<0.0001)$. However, the relatively low $P$ value for the interaction term, coupled with the large decrease in feeding on Hypnea $(-50 \%)$ but not Dictyota provide

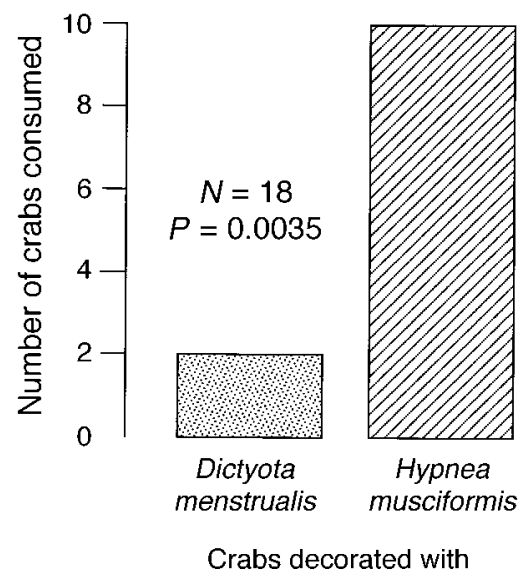

FIG. 6. Predation on field-tethered juvenile decorator crabs (Libinia dubia) camouflaged with either Dictyota or Hypnea. Data were analyzed by a $G$ test. $N=$ no. pairs of decorated crabs. 


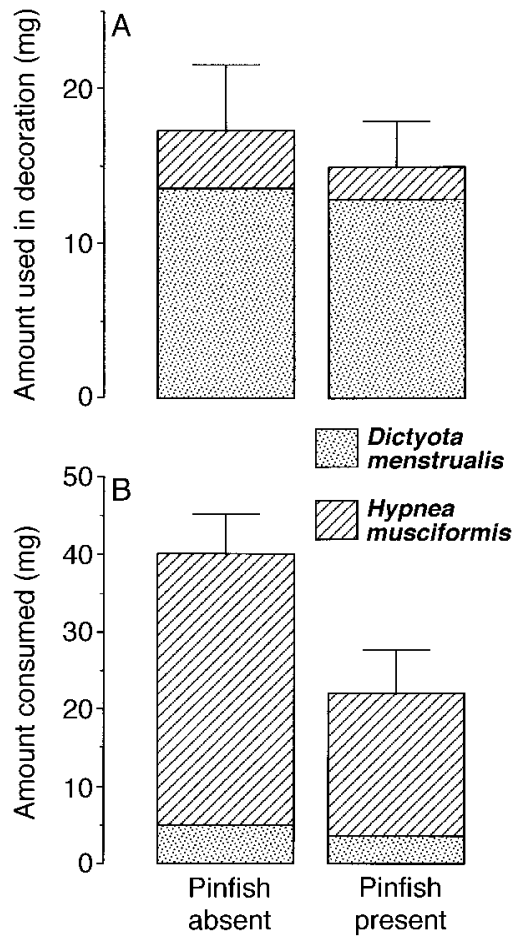

FIG. 7. The effects of predator presence on the amount (mean $+1 \mathrm{SE})$ and species composition of seaweeds used as camouflage (A) and as food (B) by the decorator crab, Libinia dubia, over a 24-h period. Error bars indicated on the figure are for the total amount of seaweed consumed or used as decoration in each treatment. The seaweed amounts were compared by two-way analyses of variance $(N=15)$ : for (A), species $P=0.0002$, predator $P=0.610$, species $\times$ predator interaction $P=0.842$; for (B), species $P<0.0001$, predator $P=0.025, \mathrm{sp} \times$ pred $P=0.081$.

a weak suggestion that crabs may avoid Hypnea (palatable to fishes) more than Dictyota in the presence of fishes.

\section{DISCUSSION}

\section{Chemically mediated camouflage}

In contrast to what has been found for other decorator crabs, which usually have camouflage that roughly reflects field availability (review by Wicksten 1980, Kilar and Lou 1986), Libinia selectively decorates with a seaweed that is relatively rare but is unpalatable to fishes (Figs. 1, 2 and 4). This behavior enhances a crab's survivorship in the field by reducing its susceptibility to predators (Fig. 6). Because the most common potential predators of small Libinia are omnivorous fishes that consume both seaweeds and crustaceans as a significant portion of their diet (Adams 1976a, Darcy 1985, Motta et al. 1995), background matching could be ineffective at reducing predator encounters if the background consists of palatable seaweeds that are consumed by omnivorous fishes. Because these fishes avoid D. menstrualis (Fig. 4) due to its potent chemical defense (Hay et al. 1987, 1988, Cronin and Hay 1996b), smaller crustaceans like crabs and amphipods that associate with this seaweed are less likely to be discovered by these fishes while foraging (Hay et al. 1987, Duffy and Hay 1991, 1994).

However, Libinia's preference for Dictyota menstrualis is not simply a consequence of the unpalatability of this species to fishes. Libinia did not camouflage with other species, such as Padina, that are equally low preference foods for fishes (Fig. 2B and 4, see also Hay et al. 1987, 1988). Crabs also did not camouflage with a congener of D. menstrualis, D. ciliolata (Fig. 2B), despite the fact that this seaweed produces a dictyolclass compound (dictyol B acetate) that strongly deters feeding by fishes both at and below natural concentration (Cronin and Hay 1996b). In North Carolina, D. ciliolata occurs primarily on rocky substrates and in deeper water and is rarely found in seagrass beds, so this alga rarely co-occurs with Libinia on a local scale. This lack of use of a chemically defended congener emphasizes the specificity of Libinia's strong preference for D. menstrualis.

The proximate mechanism for this preference is that crabs cue specifically on dictyol E (Fig. 5A-D), an herbivore-deterrent secondary metabolite produced by D. menstrualis (and not D. ciliolata). Fish feeding is much more sensitive to natural levels of dictyol E than other compounds in D. menstrualis; feeding by pinfish is strongly deterred by natural, or lower, levels of dictyol E (Cronin and Hay 1996b), but three to seven times the natural concentration of pachydictyol $\mathrm{A}$ is required to deter pinfish feeding (Cronin and Hay 1996a). Thus, the compound that stimulates decoration in Libinia is also the one that is most deterrent to the most common potential predator; in effect, Libinia is behaviorally sequestering the defensive chemistry of Dictyota. The reverse of this process may occur for herbivorous mites that use volatile plant chemicals as cues to disperse from plants where predators are likely to be abundant (Dicke et al. 1990).

Although there are many instances of predators using chemically mediated camouflage to ambush prey in a "wolf-in-sheep's-clothing" strategy (e.g., Eisner et al. 1978, McMahan 1982, Stowe et al. 1987, Stowe 1988, Breed et al. 1992), there are few rigorous demonstrations of prey using chemical camouflage to avoid predators. In a study somewhat similar to this one, Hay et al. (1990) demonstrated that a tropical marine amphipod builds domiciles from a chemically defended seaweed and uses that seaweed's deterrent metabolites as a cue for domicile building. When in this domicile, the amphipod's susceptibility to fish predation is greatly reduced compared to amphipods without domiciles, but the effectiveness of this defense has been tested only in the laboratory. It also appears that the limpet Notoacmea paleacea may avoid detection by predatory starfish by incorporating compounds from the surfgrass Phyllospadix into its shell and thus being chemically indistinguishable from its surfgrass host (Fishlyn and 
Phillips 1980); however, evidence for this is circumstantial. In terrestrial systems, the Siberian chipmunk (Eutamias sibiricus asiaticus) is known to rub gnawed flesh from dead snakes onto its fur as a possible scentbased deterrence to predators (Kobayahsi and Watanabe 1986). In a laboratory setting, the application of this "snake scent" to dead laboratory mice marginally reduced their probability of being eaten by snakes $(P$ $=0.09$ [Kobayahsi and Watanabe 1986]), but field tests of the adaptive value of this behavior to chipmunks have yet to be carried out. To our knowledge, this study of Libinia's decoration behavior is the first rigorous demonstration that camouflage behavior mediated by a deterrent chemical reduces an organism's susceptibility to predators in the field.

\section{Specialization to avoid predators}

There is debate among both terrestrial and marine ecologists about the forces that drive the evolution of specialization by herbivores. Although herbivores might specialize on noxious plants to avoid competition for food, competition for food among arthropods is relatively rare and predators and pathogens, rather than food limitation, appear to control populations of many herbivorous insects (Strong et al. 1984). Plant secondary chemicals perform many ecologically relevant functions in addition to deterring herbivores, including suppression of competitors (Schmitt et al. 1995), screening of ultraviolet radiation (Rozema et al. 1997), and preventing infections by pathogens (Bernays et al. 1989, Gil-Turnes et al. 1989, Paul 1992). Because these metabolites can have consequences for organisms other than herbivores, plant secondary metabolites in some cases indirectly benefit herbivores by decreasing the fitness of the herbivores' natural enemies more than they reduce the fitness of the herbivore itself (reviews by Hay 1992, Schultz 1992, Hay and Fenical 1996). Thus, the indirect consequences of suppressing losses to natural enemies may be more important to specialist herbivores than the host-plant's nutritional value in determining food choice.

However, because most small herbivores use a hostplant as both food and shelter, the roles of diet selection and predator avoidance in driving ecological specialization are often confounded. In contrast, because $\mathrm{Li}$ binia carries a patch of enemy-deterrent habitat along with it, diet choice is not constrained by habitat choice. Our data clearly indicate that predation pressure rather than diet selection drives specialization in this crab because Libinia (1) shows extreme specialization in selection of camouflage (Figs. 1 and 2B) that is mediated by a plant-specific chemical cue (Fig. 5C and D); (2) is fairly generalized in diet selection, consuming at least some of all species offered (Fig. 2A); and (3) experiences reduced susceptibility to predation as a result of this specialized decoration behavior (Fig. 6).

Our contrast of adult and juvenile camouflage behavior may provide additional support for predation as the primary driver of this specialized behavior. While juvenile crabs decorated selectively in the field and the laboratory, adults rarely decorated at all (Fig. 2D). Other decorator crab species also decorate as juveniles but not as adults (Wicksten 1979). Although we cannot be sure of the reason for this ontogenetic change in behavior, larger individuals of many species are less susceptible to predators (e.g., Vince et al. 1976, Hughes and Elner 1979), so the benefits of camouflage may decline with increasing size. For predatory fishes, the upper size limit of prey consumed is often set by the width of the mouth, as increased handling time associated with consuming extremely large prey make them less profitable than smaller prey (Werner 1974, 1977, Wainwright and Richard 1995, Wainwright 1996). While many of the fishes present in grassbed habitats are capable of consuming juvenile Libinia, few (if any) appear likely to consume the much larger adults (Fig. 3 ). Because the adult crabs that do not decorate have body masses 20 times as great as the juveniles that do decorate, and are not only larger than the gape of the fishes but larger than many of the fishes themselves, we expect that their susceptibility to predators would be dramatically reduced. Camouflaging may be costly for crabs, as the search time required to locate and affix proper camouflage materials may be high due to the relative rarity of preferred materials (Fig. 1A), and camouflage may increase drag and cause dislodgement from the substrate. These costs may select for the abandonment of camouflage behavior among adults as benefits diminish.

\section{Other predator avoidance behaviors}

The generality in food selection exhibited by these crabs (Fig. 2A) may also reduce predation risk by minimizing the distance traveled while foraging. Unlike some amphipods and many herbivorous insects, these crabs do not live on the plants they consume, so they must forage for food at each meal. But because Libinia can consume a wide variety of algae (Fig. 2A), it may need to move less to meet nutritional requirements than a grazer with a more limited diet. Thus, a broad diet may allow Libinia to reduce the time spent foraging because many prey are acceptable, thereby enhancing the effectiveness of the camouflage by reducing overall movement (Endler 1986). Other spider crabs (Majidae) exhibit even broader diets and some commonly consume seaweeds like Dictyota and Halimeda that produce potent chemical defenses (Stachowicz and Hay 1996). These crabs typically associate with calcified seaweeds or hard corals, and they have high site fidelity and low mobility because they must remain on, or near, their sessile host for protection from predators (Stachowicz and Hay 1996; J. Stachowicz and M. Hay, unpublished data). Because Libinia carries its shelter with it, it may be able to increase its mobility and avoid having to consume whatever seaweeds occur near its host. Although our evidence is circumstantial, preda- 
tors may indirectly affect diet breadth by restricting herbivore mobility.

Libinia showed some ability to adjust activity levels to match perception of predation risk by reducing food consumption in the presence of a predator (Fig. 7B). Reduced feeding activity and increased use of refuges is a common behavioral response to increased predation risk among aquatic animals (e.g., Werner et al. 1983, Sih 1986, Gilliam and Fraser 1987, Sih et al. 1992, Vadas et al. 1994), and this increased use of refuges may enhance the effectiveness of Libinia's camouflage by reducing the probability of detection by predators. In contrast to feeding, camouflage behavior was unaltered by predator presence (Fig. 7A). Many animals stay in spatial refuges from predators such as crevices or vegetation as a way of life despite temporal variation in predation pressure because the cost of obtaining information about predator density is too great (Sih 1987). Similarly, juvenile Libinia probably exhibits little plasticity in camouflage behavior because the cost of not camouflaging properly (i.e., not maintaining a refuge from predators) is high (Fig. 6) and likely outweighs any potential benefits associated with reallocation of energy to other tasks.

\section{Geographic variation in behavior}

Between northern Virginia and Cape Cod, Massachusetts, Libinia cannot decorate with Dictyota menstrualis because this alga does not occur there. In this portion of its range, we do not know whether Libinia (1) specializes on other chemically defended species, (2) generalizes and attempts to match the background vegetation like other decorator crabs (Kilar and Lou 1986), or (3) ceases to camouflage altogether. The decreased predation pressure typical of higher latitudes (Bertness et al. 1981, Menge and Lubchenco 1981, Heck and Wilson 1987, Coley and Aide 1990, Bolser and Hay 1996) could diminish selection for camouflaging behavior in the same way that the decreased predation risk of larger crabs (cf. Fig. 3) may relax selection for camouflaging in adults. Many species that interact strongly do not have completely overlapping ranges, and populations outside the area of overlap may lose some of the adaptations for the interaction (e.g., Janzen 1973, Rickson 1977). It is thus possible that the chemically mediated recognition of dictyol E from $D$. menstrualis represents a local or regional adaptation for predator avoidance in the southern portion of the range of Libinia, although broad-scale sampling is needed to confirm this hypothesis. Such variation in the nature and degree of specialization, driven by local or regional differences in predation pressure, can have profound evolutionary consequences (Thompson 1994, Travis 1996) and clearly warrants further attention from ecologists.

\section{ACKNOWLEDGMENTS}

This investigation was supported by the National Science Foundation through grant No. OCE 95-29784 to M. E. Hay and a pre-doctoral fellowship to J. Stachowicz. We thank Niels Lindquist for advice on chemical techniques and $\mathrm{J}$. Grabowski and P. Levin for help in collecting crabs and fishes. Comments from Jim Coleman and two anonymous reviewers improved the manuscript.

\section{Literature Cited}

Adams, S. M. 1976a. Feeding ecology of eelgrass fish communities. Transactions of the American Fisheries Society 105:514-519.

1976b. The ecology of eelgrass, Zostera marina (L.), fish communities. I. Structural analysis. Journal of Experimental Marine Biology and Ecology 22:269-291.

Aldredge, J. R., and J. T. Ratti. 1986. Comparison of some statistical techniques for analysis of resource selection. Journal of Wildlife Management 50:157-165.

Barbosa, P. 1988. Some thoughts on "the evolution of host range." Ecology 69:912-915.

Bernays, E. A. 1989. Host range in phytophagous insects: the potential role of generalist predators. Evolutionary Ecology 3:299-311.

Bernays, E. A., and R. F. Chapman. 1987. Chemical deterrence of plants. Pages 100-141 in Coevolution of plants and animals. J. B. Harborne, editor. Academic Press, New York, New York, USA.

Bernays, E. A., G. C. Driver, and M. Bilgener. 1989. Herbivores and plant tannins. Advances in Ecological Research 19:263-302.

Bernays, E. A., and M. Graham. 1988. On the evolution of host specificity in phytophagous insects. Ecology 69:886892.

Bertness, M. D., S. D. Garrity, and S. C. Levings. 1981. Predation pressure and gastropod foraging: a tropical-temperate comparison. Evolution 35:995-1007.

Bolser, R. C., and M. E. Hay. 1996. Are tropical plants better defended? Palatability and defenses of temperate vs. tropical seaweeds. Ecology 77:2269-2286.

Breed, M. D., L. E. Snyder, T. L. Lynn, and J. A. Morhart. 1992. Acquired chemical camouflage in a tropical ant. Animal Behaviour 44:519-523.

Bryant, J. P., P. B. Reichardt, T. P. Clausen, F. D. Provenza, and P. J. Kuropat. 1992. Woody plant-mammal interactions. Pages 344-371 in G. A. Rosenthal and M. R. Berenbaum, editors. Herbivores: their interactions with plant secondary metabolites. Second edition. Volume two: Ecological and evolutionary processes. Academic Press, San Diego, California, USA.

Coley, P. D., and T. M. Aide. 1990. Comparison of herbivory and plant defenses in temperate and tropical broad-leaved forests. Pages 25-49 in P. W. Price, T. M. Lewinsotin, G. W. Fernandes, and W. W. Benson, editors. Plant-animal interactions: evolutionary ecology in tropical and temperate regions. John Wiley and Sons, New York, New York, USA.

Conover, W. J. 1980. Practical nonparametric statistics. Second edition. John Wiley and Sons, New York, New York, USA.

Courtney, S. 1988. If it's not coevolution it must be predation? Ecology 69:910-911.

Cronin, G. C., and M. E. Hay. 1996a. Susceptibility to herbivores depends on recent history of both the plant and animal. Ecology 77:1531-1543.

Cronin, G. C., and M. E. Hay. 1996b. Induction of seaweed chemical defenses by amphipod grazing. Ecology 77:22872301.

Cronin, G. C., N. Lindquist, M. E. Hay, and W. Fenical. 1995. Effects of storage and extraction procedures on yields of lipophilic metabolites from the brown seaweeds Dictyota ciliolata and D. menstrualis. Marine Ecology Progress Series 119:265-273.

Darcy, G. H. 1985. Synopsis of biological data on the pinfish Lagodon rhomboides (Pisces: Sparidae). National Oceanic 
and Atmospheric Administration Technical Report, National Marine Fisheries Service No. 23, U.S. Department of Commerce, National Technical Information Service, Springfield, Virginia, USA.

Dicke, M., M. W. Sabelis, J. Takabayashi, J. Bruin, M. A. Posthumus. 1990. Plant strategies of manipulating predator-prey interactions through allelochemicals: prospects for application in pest control. Journal of Chemical Ecology 16:3091-3118

Duffy, J. E., and M. E. Hay. 1991. Food and shelter as determinants of food choice by an herbivorous marine amphipod. Ecology 72:1286-1298.

Duffy, J. E., and M. E. Hay. 1994. Herbivore resistance to seaweed chemical defense: the roles of mobility and predator risk. Ecology 75:1304-1319.

Ehrlich, P. R., and D. D. Murphy. 1988. Plant chemistry and host range in insect herbivores. Ecology 69:908-909.

Ehrlich, P. R., and P. H. Raven. 1964. Butterflies and plants: a study in coevolution. Evolution 18:586-608.

Eisner, T., K. Hicks, M. Eisner, and D. S. Robson. 1978. "Wolf-in-sheep's-clothing" strategy of a predaceous insect larva. Science 199:790-794.

Endler, J. A. 1986. Defense against predators. Pages 109134 in Predator-prey relationships. M. E. Feder and G. V. Lauder, editors. University of Chicago Press, Chicago, Illinois, USA.

Fishlyn, D. A., and D. W. Phillips. 1980. Chemical camouflaging and behavioral defenses against a predatory seastar by three species of gastropods from the surfgrass Phyllospadix community. Biological Bulletin 158:34-48.

Fox, L. R. 1988. Diffuse coevolution within complex communities. Ecology 69:906-907.

Futuyma, D. J., and G. Moreno. 1988. The evolution of ecological specialization. Annual Review of Ecology and Systematics 19:207-233.

Gilliam, J. F., and D. F. Fraser. 1987. Habitat selection under predation hazard: test of a model with foraging minnows. Ecology 68:1856-1862.

Gil-Turnes, M. S., M. E. Hay, and W. Fenical. 1989. Symbiotic marine bacteria chemically defend crustacean embryos from a pathogenic fungus. Science 246:116-118.

Hay, M. E. 1992. The role of seaweed chemical defenses in the evolution of feeding specialization and in the mediation of complex interactions. Pages 93-118 in Ecological roles of marine natural products. V. J. Paul, editor. Comstock, Ithaca, New York, USA.

- 1996. Marine chemical ecology: what is known and what is next? Journal of Experimental Marine Biology and Ecology 200:103-134.

Hay, M. E., J. E. Duffy, and W. Fenical. 1990. Host-plant specialization decreases predation on a marine amphipod: an herbivore in plant's clothing. Ecology 71:733-743.

Hay, M. E., J. E. Duffy, C. A. Pfister, and W. Fenical. 1987 Chemical defense against different marine herbivores: are amphipods insect equivalents? Ecology 68:1567-1580.

Hay, M. E., and W. Fenical. 1988. Marine plant-herbivore interactions: the ecology of chemical defense. Annual Review of Ecology and Systematics 19:111-145.

Hay, M. E., and W. Fenical. 1996. Chemical ecology and marine biodiversity: insights and products from the sea. Oceanography 9:10-20.

Hay, M. E., P. E. Renaud, and W. Fenical. 1988. Large mobile versus small sedentary herbivores and their resistance to seaweed chemical defense. Oecologia 75:246-252.

Hay, M. E., and P. D. Steinberg. 1992. The chemical ecology of plant-herbivore interactions in marine vs. terrestria communities. Pages 372-413 in G. A. Rosenthal and M. R. Berenbaum, editors. Herbivores: their interactions with plant secondary metabolites. Second edition. Volume two:
Ecological and evolutionary processes. Academic Press, San Diego, California, USA.

Heck, K. L., Jr., and K. A. Wilson. 1987. Predation rates on decapod crustaceans in latitudinally separated seagrass communities: a study of spatial and temporal variation using tethering techniques. Journal of Experimental Marine Biology and Ecology 107:87-100.

Hughes, R. N., and R. W. Elner. 1979. Tactics of a predator, Carcinus maenas and morphological responses of the prey, Nucella lapillus. Journal of Animal Ecology 48:65-78.

Hunter, M. D., and J. C. Schultz. 1993. Inducible defenses breached? Phytochemical induction protects an herbivore from disease. Oecologia 94:195-203.

Janzen, D. H. 1973. Dissolution of mutualism between Cecropia and its Azteca ants. Biotropica 5:15-28.

Jermy, T. 1988. Can predation lead to narrow food specialization in phytophagous insects. Ecology 69:902-904.

Kibota, T. T., and S. P. Courtney. 1991. Jack of one trade, master of none: host choice by Drosophila magnaquinaria. Oecologia 86:251-260.

Kilar, J. A., and R. M. Lou. 1986. The subtleties of camouflage and dietary preference of the decorator crab, $M i$ crophyrs bicornutus Latreille (Decapoda: Brachyura). Journal of Experimental Marine Biology and Ecology 101:143160.

Kobayashi, T., and M. Watanabe. 1986. An analysis of snakescent application behaviour in Siberian chipmunks (Eutamias sibiricus asiaticus). Ethology 72:40-52.

Lubchenco, J., and S. D. Gaines. 1981. A unified approach to plant-herbivore interactions. I. Populations and communities. Annual Review of Ecology and Systematics 12: 405-437.

McMahan, E. A. 1982. Bait-and-capture strategy of a termite-eating assassin bug. Insectes Sociaux 29:346-351.

Menge, B. A., and J. Lubchenco. 1981. Community organization in temperate and tropical rocky intertidal habitats: prey refuges in relation to consumer pressure gradients. Ecological Monographs 51:429-450.

Motta, P. J., K. B. Clifton, P. Hernandez, B. T. Eggold, S. D. Giordano, and R. Wilcox. 1995. Feeding relationships among nine species of seagrass fishes of Tampa Bay, Florida. Bulletin of Marine Science 56:185-200.

Paul, V. J. 1992. Ecological roles of marine natural products. Comstock, Ithaca, New York, USA.

Peterson, C. H., and P. E. Renaud. 1989. Analysis of feeding preference experiments. Oecologia 80:82-86.

Price, P. W., C. E. Bouton, P. Gross, B. A. McPherson, J. N. Thompson, and A. E. Weiss. 1980. Interactions among three trophic levels: influence of plants on interactions between herbivores and natural enemies. Annual Review of Ecology and Systematics 11:41-65.

Price, P. W., M. Westoby, B. Rice, P. R. Atsatt, R. S. Fritz, J. N. Thompson, and K. Mobley. 1986. Parasite mediation in ecological interactions. Annual Review of Ecology and Systematics 17:487-505.

Rausher, M. D. 1988. Is coevolution dead? Ecology 69:898901.

Renaud, P. E., M. E. Hay, and T. M. Schmitt. 1990. Interactions of plant stress and herbivory: intraspecific variation in the susceptibility of a palatable versus an unpalatable seaweed to sea urchin grazing. Oecologia 82:217-226.

Rickson, F. R. 1977. Progressive loss of ant-related traits of Cecropia peltata on selected Caribbean Islands. American Journal of Botany 64:585-592.

Rosenthal, G. A., and M. R. Berenbaum. 1992. Herbivores: their interactions with plant secondary metabolites. Second edition. Volume two: Ecological and evolutionary processes. Academic Press, San Diego, California, USA.

Ross, S. W., and M. L. Moser. 1995. Life history of juvenile 
gag, Mycteroperca microlepis, in North Carolina estuaries. Bulletin of Marine Science 56:222-237.

Rowell-Rahier, M., and J. M. Pasteels. 1992. Third trophic level influences of plant allelochemicals. Pages 243-278 in G. A. Rosenthal and M. R. Berenbaum, editors. Herbivores: their interactions with plant secondary metabolites. Second edition. Volume two: Ecological and evolutionary processes. Academic Press, San Diego, California, USA.

Rozema, J., J. van de Staaij, L. O. Bjorn, and M. Caldwell. 1997. UV-B as an environmental factor in plant life: stress and regulation. Trends in Ecology and Evolution 12:2228.

Schmitt, T. M., M. E. Hay, and N. Lindquist. 1995. Constraints on chemically mediated coevolution: multiple functions for seaweed secondary metabolites. Ecology 76:107123.

Schneider, C. W., and R. B. Searles. 1991. Seaweeds of the southeastern United States: Cape Hatteras to Cape Canaveral. Duke University Press, Durham, North Carolina, USA

Schultz, J. C. 1988. Many factors influence the evolution of herbivore diets, but plant chemistry is central. Ecology 69 : 896-897.

. 1992. Factoring natural enemies into plant tissue availability to herbivores. Pages 175-199 in M. D. Hunter, T. Ohgushi, and P. W. Price, editors. Effects of resource distribution on animal-plant interactions. Academic Press, San Diego, California, USA.

Schultz, J. C., M. A. Foster, and M. E. Montgomery. 1990. Host-plant mediated impacts of a baculovirus on gypsy moth populations. Pages 303-313 in A. D. Watt, S. R. Leather, M. D. Hunter, and N. A. C. Kidd, editors. Population dynamics of forest insects. Intercept Press, Andover, UK.

Schwartz, F. J., and B. W. Dutcher. 1963. Age, growth, and food of the oyster toadfish near Solomons, Maryland. Transactions of the American Fisheries Society 92:170173.

Sih, A. 1986. Anti-predator responses and the perception of danger by mosquito larvae. Ecology 67:434-441.

1987. Predators and prey lifestyles: an evolutionary and ecological overview. Pages 203-224 in W. C. Kerfoot and A. Sih, editors. Predation: direct and indirect impacts on aquatic communities. University Press of New England, Hanover, New Hampshire, USA.

Sih, A., L. B. Kats, and R. D. Moore. 1992. Effects of predatory sunfish on the density, drift, and refuge use of stream salamander larvae. Ecology 73:1418-1430.

Slansky, F. 1992. Allelochemical-nutrient interactions in herbivore nutritional ecology. Pages 135-174 in G. A. Rosenthal and M. R. Berenbaum, editors. Herbivores: their interactions with plant secondary metabolites. Second edition. Volume two: Ecological and evolutionary processes. Academic Press, San Diego, California, USA.

Stachowicz, J. J., and M. E. Hay. 1996. Facultative mutu- alism between an herbivorous crab and a coralline alga: advantages of eating noxious seaweeds. Oecologia 105: 377-387.

Stowe, M. K. 1988. Chemical mimicry. Pages 513-580 in K. C. Spencer, editor. Chemical mediation of coevolution. Academic Press, San Diego, California, USA.

Stowe, M. K., J. H. Tumlinson, and R. R. Heath. 1987. Chemical mimicry: bolas spiders emit components of moth prey species sex pheromones. Science 236:964-967.

Strong, D. R., J. H. Lawton, and T. R. E. Southwood. 1984. Insects on plants: community patterns and mechanisms. Blackwell Scientific, Oxford, UK.

Thompson, J. N. 1988. Coevolution and alternative hypotheses on insect/plant interactions. Ecology 69:893-895.

. 1994. The coevolutionary process. University of Chicago Press, Chicago, USA.

Travis, J. 1996. The significance of geographical variation in species interactions. American Naturalist 148:S1-S8.

Vadas, R. L., Sr., M. T. Burrows, and R. N. Hughes. 1994. Foraging strategies of dogwhelks, Nucella lapillus (L.): interacting effects of age, diet and chemical cues to the threat of predation. Oecologia 100:439-450.

Vince, S., I. Valiela, N. Backus, and J. M. Teal. 1976. Predation by the salt marsh killifish Fundulus heteroclitus (L.) in relation to prey size and habitat structure: consequences for prey distribution and abundance. Journal of Experimental Marine Biology and Ecology 23:255-266.

Wainwright, P. C. 1996. Ecological explanation through functional morphology: the feeding biology of sunfishes. Ecology 77:1336-1343

Wainwright, P. C., and B. A. Richard. 1995. Predicting patterns of prey use from morphology with fishes. Environmental Biology of Fishes 44:97-113.

Werner, E. E. 1974. The fish size, prey size, and handling time relation in several sunfishes and some implications. Journal of the Fisheries Research Board of Canada 31: $1531-1536$.

1977. Species packing and niche complementarity in three sunfishes. American Naturalist 111:553-578.

Werner, E. E., J. F. Gilliam, D. J. Hall, and G. G. Mittelbach. 1983. An experimental test of the effects of predation risk on habitat use in fish. Ecology 64:1540-1548.

Wicksten, M. K. 1979. Decorating behavior in Loxorhynchus crispatus Stimpson and Loxorhynchus grandis Stimpson (Brachyura: Majidae). Crustaceana 5(supplement):37-46. . 1980. Decorator crabs. Scientific American 242: $146-154$.

1983. Camouflage in marine invertebrates. Oceanography and Marine Biology Annual Review 21:177-193.

Williams, A. B. 1984. Shrimps, lobsters and crabs of the Atlantic coast. Smithsonian Press, Washington, D.C., USA.

Wilson, C. A., J. M. Dean, and R. Radtke. 1982. Age, growth rate and feeding habits of the oyster toadfish, Opsanus tau, in South Carolina. Journal of Experimental Marine Biology and Ecology 62:251-259. 